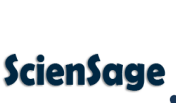

Journal of Advanced Scientific Research

Available online through https: / /sciensage.info
ISSN: 0976-9595

Short Communication

DOI: $10.55218 /$ JASR. 202213146

\title{
COMPARATIVE STUDY OF TWO SOLVENT EXTRACTS OF CITRUS LIMON LEAVES IN ALLOXAN INDUCED HYPERGLYCEMIA IN MICE
}

\author{
Krishan Kumar, Ranju Rajput \\ Department of Science and Technology, Jayoti Vidyapeeth Women's University, Jaipur, Rajasthan India \\ *Corresponding author: krishan.dr@gmail.com, ranjurajput39@gmail.com
}

\begin{abstract}
The objective of the study was comparative study of two different solvent extracts of Citrus limon leaves in alloxaninduced hyperglycemia in mice. Ethanolic and methanolic extracts of lemon leaves were prepared using a Soxhlet extractor. Diabetes was induced in mice by intraperitoneal administration of alloxan $(70 \mathrm{mg} / \mathrm{kg} \mathrm{b.w.)} \mathrm{and} \mathrm{blood} \mathrm{glucose}$ levels were measured by a glucose meter during the experimental study. The results were compared to both methanolic and ethanolic extracts at the same dose $(150 \mathrm{mg} / \mathrm{kg} \mathrm{b.w.).} \mathrm{It} \mathrm{was} \mathrm{found} \mathrm{that} \mathrm{the} \mathrm{methanolic} \mathrm{lemon} \mathrm{leaves} \mathrm{extract} \mathrm{was}$ potent than ethanolic lemon leaves extract. The results showed a significant $(\mathrm{P}<0.05)$ reduction in blood glucose revert back to near normal level in alloxan-induced diabetic mice administered with $(150 \mathrm{mg} / \mathrm{kg} \mathrm{b.w.)} \mathrm{methanolic} \mathrm{and}$ ethanolic leaves extracts. Overall, the results suggest that both ethanolic and methanolic lemon leaves extract contains an effective anti-hyperglycemic potential which may find applied in the treatment of diabetes without causing toxic effects.
\end{abstract}

Keywords: Hyperglycemia, Alloxan, Lemon leaves comparison, Glibenclamide.

\section{INTRODUCTION}

Diabetes mellitus is accredited as a group of heterogeneous disorders with common elements of hyperglycemia and glucose intolerance due to insulin deficiency, impaired insulin efficacy, or both. Type 2 diabetes is often, but not always, associated with obesity, which in itself can cause insulin resistance and increase blood glucose. It is highly familial, but major susceptibility genes have not yet been identified. Diabetes is also one of the leading causes of death, mainly due to a significantly increased risk of coronary heart disease and stroke (cardiovascular disease). Diabetes can lead to complications that can result in blindness, kidney damage, and foot ulcers that can lead to amputation. There is no single definition for each type of complication (e.g. retinopathy, neuropathy, or nephropathy), so studies of the complications of diabetes are often difficult to compare [1]. Medicinal plants, also called medicinal herbs, have been discovered and used in traditional medical practice since prehistoric times. Plants synthesize hundreds of chemical compounds for functions, including protection against insects, fungi, diseases, and herbivorous mammals. Numerous phytochemicals with potential or identified biological activity have been identified. However, because one plant contains a wide variety of phytochemicals, the effect of the whole plant as a drug is not clear [2]. Lemon is an important medicinal plant in the Rutaceae family, rich in vitamin C, alkaloids, flavonoids, and essential oils with antimicrobial and anticancer properties. Studies have shown that essential oils, protopine, corydaline, alkaloids, limonoids, lactones, polyacetylene, acyclic sesquiterpenes, hypericin, and pseudohipericin compounds present in citrus limonum are responsible for its therapeutic properties [3]. Our current study mainly deals with the identification of antidiabetic potential of the leaves of the plant Citrus limon (L.).

\section{MATERIAL AND METHODS}

\subsection{Chemicals}

Alloxan monohydrate is the product of SRL (Sisco Research Laboratories Pvt. Ltd.) (Chennai, India), the standard drug used in this experimental study was glibenclamide and other chemicals used in the study were of analytical grade purchased from local pharma shops of Jaipur.

\subsection{Collection of plant material}

Fresh matured Citrus limon leaves were collected from the campus of Jayoti Vidyapeeth women's University, Jaipur. The leaves were washed with normal Water then 
rinsed with distilled water and shade dried to remove traces of moisture and dust.

\subsection{Preparation of methanolic and ethanolic leaves extracts}

Ethanolic extract was prepared by the method of continuous soxhlet extraction. Freshly collected leaves were dried under shade and the dried material was ground to obtain a powder. The $50 \mathrm{gm}$ powder was packed in a soxhlet apparatus and extracted with $300 \mathrm{ml}$ of alcohol. The extract was concentrated at temperatures $40-50^{\circ} \mathrm{C}$ then air-dried at room temperature. The extract was preserved in the refrigerator till experimental use. The other extract was prepared as a process of ethanolic extract using methanol as the solvent.

\subsection{Experimental animals}

Normal healthy mice with an average weight of 20-30g, of both sex, were obtained from CPCSEA registered, animal house of Jayoti Vidyapeeth Women's University, Jaipur, Rajasthan. The mice were housed under standard laboratory conditions in an animal house at Jayoti Vidyapeeth Women's University and were used for the experiment. Mice were kept in polypropylene cages under controlled temperature $22-25^{\circ} \mathrm{C}$ with $12: 12 \mathrm{hrs}$ light and dark cycle. Mice were fed on a balanced diet and water ad libitum.

\subsection{Experimental Design}

Mice were separated into five groups, with six mice in each group. Group I was a non-diabetic control (NC) that received distilled water. Groups II-V fasted overnight, diabetes was induced in mice by intraperitoneal injection of $70 \mathrm{mg} / \mathrm{kg}$ alloxan monohydrate in $0.9 \% \mathrm{w} / \mathrm{v} \mathrm{NaCl}$ overnight in fasted mice. Mice were kept for the next 24 hours on $10 \%$ glucose solution bottles in cages to prevent hypoglycemia [4-6]. Three days after the increment in diabetes, mice with moderate diabetes (i.e., Blood glucose $\geq 250 \mathrm{mg} / \mathrm{dl}$ ) with hyperglycemia were selected for the experiment [7]. Group II was given distilled water as a diabetic control (DC) and group III (GB5) was given $5 \mathrm{mg} / \mathrm{kg}$ glibenclamide dissolved in saline as a standard solution, group IV (CLM150) treated with $150 \mathrm{mg} / \mathrm{kg}$ b.w. methanolic Citrus limon leaves extract, Group V (CLE150) treated with $150 \mathrm{mg} / \mathrm{kg}$ b.w. ethanolic Citrus limon leaves extract. All of these treatments were administered orally for 28 days, and on the last day, blood samples were taken by cardiac puncture and estimation of serum glucose using commercially available kits (ERBA Diagnostics Mannheim kits).

\subsection{Statistical Data Analysis}

The grouped data were statistically evaluated with SPSS (version 22.00) software. The results were expressed as Mean \pm Standard Deviation for 6 mice in each group. The statistical evaluation carried out by ANOVA (LSD) and the probability $<0.05$ was chosen as the level of significance.

\section{RESULTS AND DISCUSSION}

The results showed that Alloxan-induced diabetic mice significantly reduced the blood glucose levels in both ethanolic and methanolic extracts. The diabetic control group significantly increased the glucose level and the standard glibenclamide $5 \mathrm{mg} / \mathrm{kg}$ produced a significant reduction of blood glucose levels. From the data observation, the methanolic extract was more potent than the ethanolic extract of Citrus limon leaves. The Methanolic extract of lemon leaves and ethanolic extract of lemon leaves produced a significant reduction in blood glucose levels similar to the Glibenclamide compared to the diabetic control group, the results were represented below in the graph (Fig. 1).

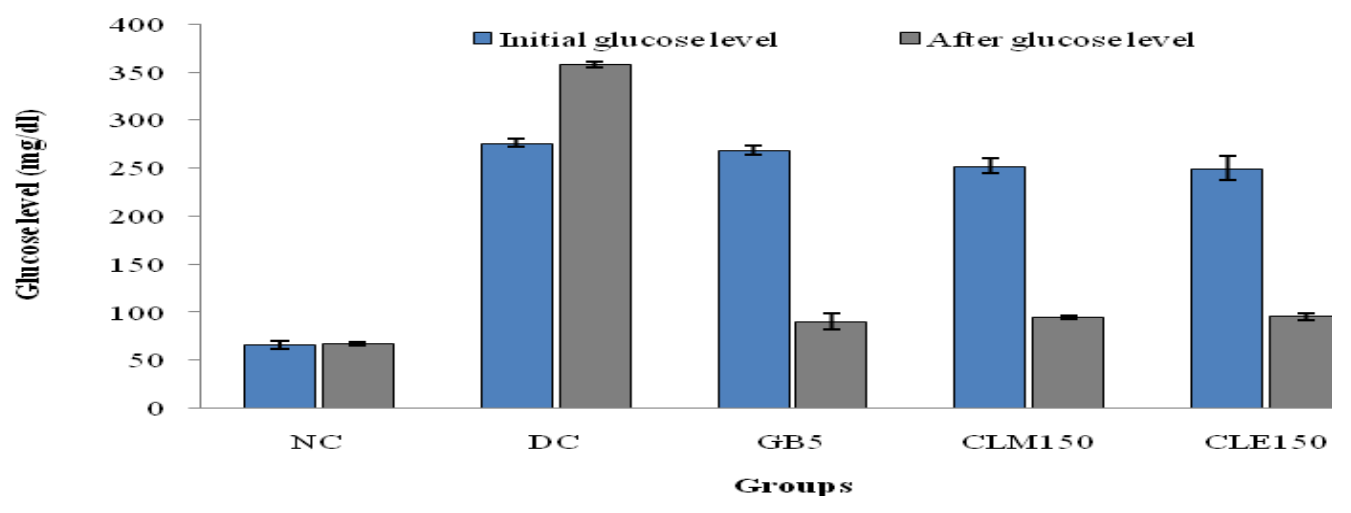

Fig. 1: Comparison of anti-hyperglycemic activity of methanolic and ethanolic extracts of Citrus limon leaves. 
Lemons have well-known nutritional and medicinal property. Citrus are one of the most popular plants in the world [8]. Citrus limon peel hexane extract, which contains about 60 volatile compounds, showed significant blood glucose lowering activity [9]. This study revealed that both extracts (ethanolic and methanolic) have antihyperglycemic potential to reduce the elevated glucose level. This study provides insight into the antidiabetic potential of lemon plants, which are used effectively in many traditional medical systems.

\section{CONCLUSION}

The results of this study revealed that both solvent extracts of lemon leaves were effective on reducing blood glucose level in alloxan induced diabetic mice. So, it can be concluded the both solvent extracts of Citrus limon leaves can significantly improve the high blood glucose level. These lemon leaves extracts were very effective in prevention of diabetes, so furthermore investigations are needed in this field to evaluate its medicinal properties.

\section{ACKNOWLEDGEMENT}

The author thanks the management of Jayoti Vidyapeeth Women's University, for support and providing the facilities to carry out the research.

\section{REFERENCES}

1. International Diabetes Federation Diabetes Atlas. Fourth edition, chapter 1, 2009; 15-20. (IDF Diabetes Atlas: www.eatlas.idf.org)

2. Verma K, Dubey R, Verma A. The Pharma Innovation, 2019; 8(6): 803-806.

3. Maruti JD, Chidamber BJ, Jai SG, et al. $B r J$ Pharmacol Toxicol. , 2011; 2(3): 119-122.

4. Jamal AAB, Issa AAH, Mohammad HHA. J. Ethnopharmacol., 1997; 58: 149-155.

5. Sabu MC, Subburaju T. J. Ethnopharmacol., 2002; 80: 203-206.

6. Aruna RV, Ramesh B, Kartha VN. Indian J. Exp. Biol., 1999; 32: 399-401.

7. Canepa ET, Llambias EB, Grinstein M. (1990). Biochem. Cell Biol., 1990; 68: 914-921.

8. Chaturvedi D, Shrivastava RR, Suhane N. Int. Res. J. Pharm., 2016; 7(6): 1-4.

9. Akhila S, Bindu AR, Bindu K, et al. World J Pharm Pharm Sci., 2015; 4(03): 1128-1135. 